Hydrology and Earth System Sciences, 5(3), 367-378 (2001) C C EGS

\title{
Are there signs of acidification reversal in freshwaters of the low mountain ranges in Germany?
}

\author{
C. Alewell ${ }^{1}$, M. Armbruster ${ }^{2}$, J. Bittersohl ${ }^{3}$, C.D. Evans ${ }^{4}$, H. Meesenburg ${ }^{5}$ K. Moritz ${ }^{3}$ and \\ A. Prechtel ${ }^{1}$
}

\footnotetext{
${ }^{1}$ Department of Soil Ecology, BITÖK, University of Bayreuth, D-95440 Bayreuth, Germany

${ }^{2}$ Institute of Soil Science, Technical University of Dresden, D-01735 Tharandt, Germany

${ }^{3}$ Bavarian Water Management Agency, D-80636 Munich, Germany

${ }^{4}$ Centre for Ecology and Hydrology, Wallingford, Oxon, OX10 8BB, United Kingdom

${ }^{5}$ Forest Research Institute of Lower Saxony, D-37079 Göttingen, Germany
}

Email for corresponding author: christine.alewell@bitoek.uni-bayreuth.de

\begin{abstract}
The reversal of freshwater acidification in the low mountain ranges of Germany is of public, political and scientific concern, because these regions are near natural ecosystems and function as an important drinking water supply. The aim of this study was to evaluate the status and trends of acidification reversal after two decades of reduced anthropogenic deposition in selected freshwaters of the low mountain ranges in the Harz, the Fichtelgebirge, the Bavarian Forest, the Spessart and the Black Forest. In response to decreased sulphate deposition, seven out of nine streams investigated had significantly decreasing sulphate concentrations (all trends were calculated with the Seasonal Kendall Test). The decrease in sulphate concentration was only minor, however, due to the release of previously stored soil sulphur. No increase was found in $\mathrm{pH}$ and acid neutralising capacity (defined by Reuss and Johnson, 1986). Aluminum concentrations in the streams did not decrease. Thus, no major acidification reversal can currently be noted in spite of two decades of decreased acid deposition. Nevertheless, the first signs of improvement in water quality were detected as there was a decrease in the level and frequency of extreme values of $\mathrm{pH}$, acid neutralising capacity and aluminium concentrations in streams. With respect to nitrogen, no change was determined for either nitrate or ammonium concentrations in precipitation or stream water. Base cation fluxes indicate increasing net loss of base cations from all ecosystems investigated, which could be interpreted as an increase in soil acidification. The latter was due to a combination of continued high anion leaching and significant reduction of base cation deposition. No major improvement was noted in biological recovery, however, initial signs of recovery were detectable as there was re-occurrence of some single macroinvertebrate species which were formerly extinct. The results of this study have important implications for water authorities, forest managers and policy makers: the delay in acidification reversal suggests a need for ongoing intensive amelioration of waters, a careful selection of management tools to guarantee sustainable management of forests and the reduction of nitrogen deposition to prevent further acidification of soils and waters.
\end{abstract}

Keywords: freshwater, acidification reversal, drinking water supply, forested catchments, Germany

\section{Introduction}

Anthropogenic atmospheric deposition has been shown to influence the biogeochemistry of forest ecosystems and accelerate soil and water acidification (Johnson et al., 1991; Ulrich and Sumner, 1991). High nitrogen (N) and/or sulphate $\left(\mathrm{SO}_{4}\right)$ deposition has resulted in $\mathrm{N}$ and $\mathrm{SO}_{4}$ accumulation in forest soils, and acidification of surface waters. Furthermore, loss of base cations from forest soils can be accelerated by acid rain (Rhode et al., 1995; BML, 1997; Yanai et al., 1999). The decrease in anthropogenic deposition of protons $\left(\mathrm{H}^{+}\right)$ and $\mathrm{SO}_{4}$ in German forest ecosystems during the last two decades has raised questions concerning the reversibility of acidification (defined here as reversing trends of chemical parameters) and the biological recovery of ecosystems.

Trends in freshwater acidification and the recovery of streams and groundwaters in the low mountain regions of Germany are of public, political and scientific concern, because the forested catchments of these regions are near natural ecosystems and are a major source of drinking water. The allowable range of acidity for drinking water in Germany is $6.5 \leq \mathrm{pH} \leq 9.5$ (LfW, 1997). Even though acidified water in itself is not toxic to humans as long as $\mathrm{pH}$ 
is between $4 \leq \mathrm{pH} \leq 10$, acidified waters will accelerate plumbing corrosion and contribute to leaching of potentially toxic and/or irritating metals such as lead $(\mathrm{Pb})$, iron $(\mathrm{Fe})$, copper $(\mathrm{Cu})$, aluminium $(\mathrm{Al})$ and manganese $(\mathrm{Mn})(\mathrm{LfW}$, 1997). Water acidity in forested catchments is connected to leaching of $\mathrm{Al}, \mathrm{Fe}$, and $\mathrm{Mn}$ from forest soils. High $\mathrm{Al}$ concentrations in waters have been shown to be toxic for fish (Driscoll et al., 1980; Baker and Schofield, 1982), and amphipods (Musibono and Day, 1999) and are suggested to be harmful for humans (Struys-Ponsar et al., 2000; Yokel, 2000). Human neurotoxicity of metals has been shown to be increased by interactions of various metal species such as $\mathrm{Al}, \mathrm{Fe}, \mathrm{Mn}, \mathrm{Cu}$ and zinc (Zn) (Verity, 1999; Christen, 2000). Furthermore, the acidification of soils and soil solutions has been shown to cause problems with forest nutrition and is one cause for forest dieback (Lorenz, 1995; Müller-Edzards et al., 1997; Alewell et al., 2000a), even though the link between forest condition and soil acidification is difficult to validate (Cronan and Grigal, 1995; Erisman et al., 1997; De Wit, 2000).

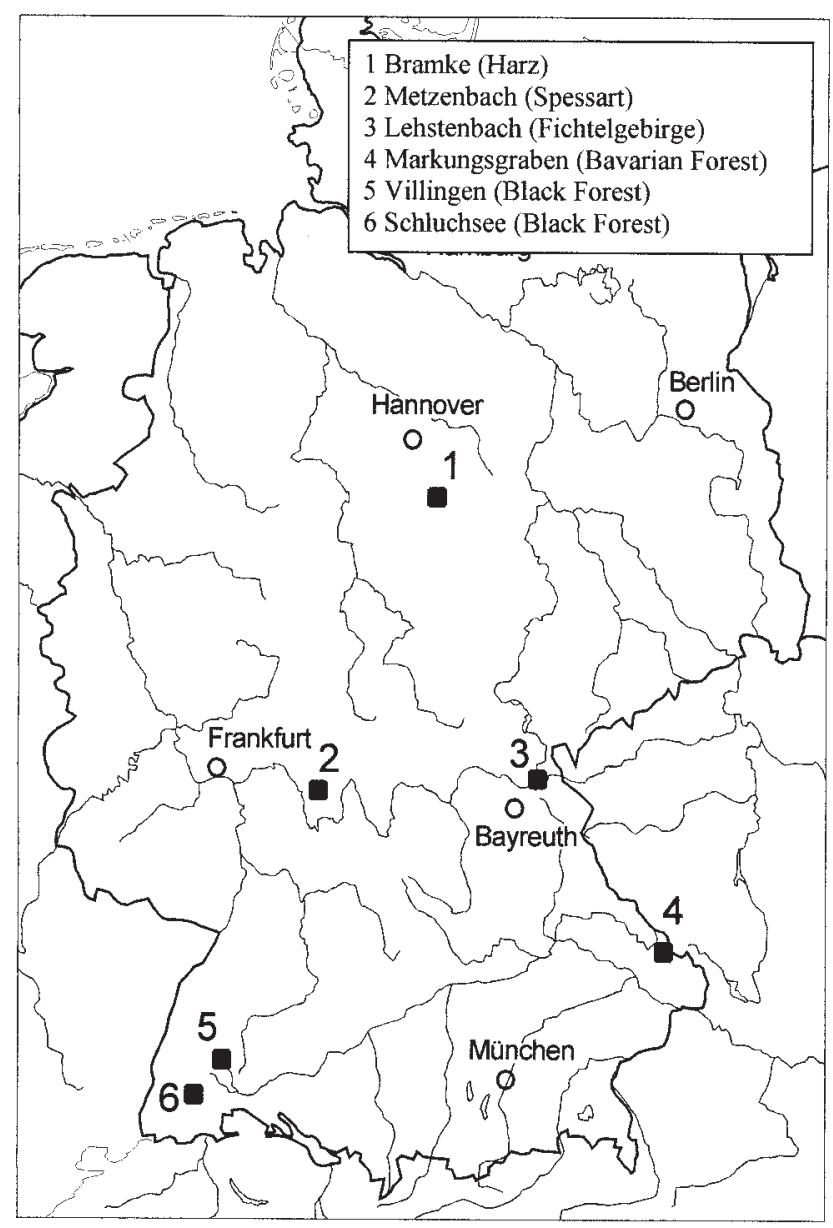

Regions investigated in this study are low mountain ranges in Germany (see Fig. 1). Groundwater and springs draining these regions are an important drinking water resource in acidified regions in Bavaria. The major part has been shown to exceed the permitted drinking water contaminant level for several parameters between 1988 and 1994 (LfW, 1997), prompting additional efforts for water treatment (deacidification, Al purification) especially in small water plants. Of the freshwaters investigated (mostly untreated water samples from groundwater supplies) in the Spessart, the Fichtelgebirge and the Bavarian Forest, 87, 94, and 98\%, respectively, had average $\mathrm{pH} \leq 6.5$ between 1988-1994 ( $\mathrm{n}=62,74,120$, respectively, LfW, 1997). Approximately $20-40 \%$ of the groundwater samples had $\mathrm{Al}>0.05 \mathrm{mg} \mathrm{l}^{-1}$, which is the drinking water guideline value recommended by the EU (note that the drinking water contaminant level in Germany is $0.2 \mathrm{mg} \mathrm{l}^{-1}$ which is exceeded in 3,19 and $9 \%$ of the investigated groundwaters in the Spessart, the Fichtelgebirge and the Bavarian Forest, respectively; LfW, 1997). A similar situation is found for the Black Forest where $\mathrm{pH}$ values $<5$ and $\mathrm{Al}$ concentrations $>0.2 \mathrm{mg} \mathrm{l}^{-1}$ were frequently measured in groundwaters (Hinderer and Einsele, 1998). One consequence of freshwater acidification is an increasing effort to ameliorate water quality (mainly deacidification and $\mathrm{Al}$ purification) before consumption as drinking water. Between 1988 and 1994, 21\% of all treated waters (average values for all low mountain ranges in Bavaria investigated by the Bavarian Water Management Agency) had $\mathrm{pH} \leq 6.5$ which is outside the contaminant level for drinking water ( $\mathrm{LfW}, 1997)$. In the case of $\mathrm{Al}, 68 \%$ of all treated drinking water had values above $0.05 \mathrm{mg} \mathrm{l}^{-1}$ and $15 \%$ exceeded $0.2 \mathrm{mg} \mathrm{l}^{-1}$ between 1988 and 1994 (LfW, 1997).

The biological recovery of streams draining the low mountain ranges in Germany is of minor public concern because in many streams fish have been absent for several decades. Nevertheless, the biological recovery of species communities in these streams is of ecological value which should not be ignored. In some streams of the Harz Mountains (Lange Bramke) or the Black Forest trout are still present in spite of acidification (Gebhardt, 1994; Leßmann et al., 1994).

The aim of this study was the evaluation of trends in freshwater acidification in the low mountain ranges of Germany, namely, the Spessart, the Fichtelgebirge, the Bavarian Forest, the Harz mountains and the Black Forest. The likelihood of an acidification reversal in the near future and the consequences for water authorities, forest management and policy makers are discussed.

Fig. 1. Location of sites 


\section{Methods}

\section{SITE DESCRIPTIONS}

The Bramke area is located in the Harz mountains. The Lange Bramke catchment (51 $\left.52^{\prime} \mathrm{N}, 10^{\circ} 26^{\prime} \mathrm{E}\right)$ with an altitudinal range of 543 to $700 \mathrm{~m}$ a.s.l. has an area of 76 ha and is stocked with 54 years old spruce. Lange Bramke spring is a subcatchment of Lange Bramke. Dicke Bramke and Steile Bramke with catchment areas of 32 and 38 ha, respectively, are stocked with 20 to 110 years old spruce stands. The Steile Bramke catchment was limed in 1989 with $16 \mathrm{t} \mathrm{ha}^{-1}$ of dolomitic limestone (Meesenburg et al., 2001). Average annual precipitation (1949-1995) was 1230 mm and average temperature $6^{\circ} \mathrm{C}$ (Schmidt, 1997). Bedrock consists mainly of sandstones with layers of calcareous sand and clay schist (geological formation Oberemsstufe of the Lower Devonia). Soils comprise dystric Cambisols and haplic Podzols. A small proportion (4.5\%) of the Lange Bramke catchment is permanently waterlogged. The upland soils are acidic with $2.8<\mathrm{pH}\left(\mathrm{CaCl}_{2}\right)<4.4$. Per cent base saturation of cation exchange capacity (CEC) is below $6 \%$ in the upper $20 \mathrm{~cm}$ and below $10 \%$ in the lower mineral soil (down to $1 \mathrm{~m}$ depth).

The Metzenbach catchment ( 240 ha, $\left.49^{\circ} 54^{\prime} \mathrm{N}, 9^{\circ} 26^{\prime} \mathrm{E}\right)$ is located in the low mountain range, Spessart, southeast of Frankfurt at an elevation of 380-568 m a.s.1. Bedrock consists mostly of fine grained sandstones (geological formation Bunter Sandstone) and the soils are predominantly Cambisols. $20 \%$ of the catchment soils are influenced by permanent or temporary water saturation. Soils are very acidic with $\mathrm{pH}\left(\mathrm{CaCl}_{2}\right)$ between 2.9 and 4.0. Base saturation is below $15 \%$ in the upper soils but increases to $>20 \%$ in $2-$ $4 \mathrm{~m}$ depth. Mean air annual temperature is $7^{\circ} \mathrm{C}$ and annual average precipitation is 950-1100 mm (1988-1999). The catchment is stocked with beech and oak.

The Lehstenbach catchment $\left(4.2 \mathrm{~km}^{2}, 50^{\circ} 09^{\prime} \mathrm{N}, 11^{\circ} 52^{\prime} \mathrm{E}\right)$ is located in the Fichtelgebirge area in Northern Bavaria close to the border with the Czech Republic at a height of 695-875 $\mathrm{m}$ a.s.1. The granite bedrock was deeply weathered during the Tertiary. The average precipitation in the area is $1000 \mathrm{~mm}$ and the annual average temperature is $6^{\circ} \mathrm{C}(1988-$ 1999). The soils in the upland part of the catchment are acidic and have been classified as dystric Cambisols and Podzols according to FAO-classification. $30 \%$ of the catchment is covered by boggy areas where soils have been classified as fibric Histosols and dystric Gleysols. Base saturation of the mineral soils down to $2.5 \mathrm{~m}$ is less then $10 \%$. Ninety per cent of the catchment is stocked with Norway spruce (Picea abies (L.) Karst.) of various age classes.

The Markungsgraben catchment $\left(48^{\circ} 57^{\prime} \mathrm{N}, 13^{\circ} 25^{\prime} \mathrm{E}\right)$ is a subcatchment of the catchment Große Ohe in the Bavarian Forest National Park on the Bavarian-Czech border. Markungsgraben has an area of $1.1 \mathrm{~km}^{2}$ at an altitude of $890-1355 \mathrm{~m}$ a.s.l. Average slope inclination is $27 \%$. Bedrock consists of coarse granite and gneiss with deeply weathered portions and periglacial and glacial overburden (Moritz and Bittersohl, 2000). Mineral soils (classified as Cambisols and dystric Cambisols) are acidic $\left(\mathrm{pH}\left(\mathrm{CaCl}_{2}\right) 3.5\right.$ to 4.0$)$ and base saturation is below $10 \%$ at $30 \mathrm{~cm}$ depth. The catchment is completely forested with spruce in the highland region and mixed woodlands in the lower slope regions. Average annual precipitation is $1680 \mathrm{~mm}$ with an average annual air temperature of $5.6^{\circ} \mathrm{C}$ (1989-1996, Moritz and Bittersohl, 2000).

The Villingen (46 ha, $48^{\circ} 03^{\prime} \mathrm{N}, 8^{\circ} 22^{\prime} \mathrm{E}$ ) and Schluchsee (11 ha, 47 $49^{\prime} \mathrm{N}, 8^{\circ} 06^{\prime} \mathrm{E}$ ) catchments are both located in the Black Forest at altitudes of $870-950 \mathrm{~m}$ a.s.1. and $1150-$ $1250 \mathrm{~m}$ a.s.1., respectively. Both catchments are stocked with spruce with an average age of 110 and 55 years, for Villingen and Schluchsee, respectively. Bedrock is sandstone (geological formation Bunter sandstone) in the case of Villingen and granite (geological formation Bärhaldegranit) in Schluchsee. Soils in Villingen are acidic and have developed to dystric Cambisols (70\%) and dystric Planosols (30\%) (Armbruster, 1998). Soil $\mathrm{pH}\left(\mathrm{CaCl}_{2}\right)$ is $<4$ and base saturation $<7 \%$ down to $1 \mathrm{~m}$ depth, with the exception of a clay layer at $70 \mathrm{~cm}$ depth in the Planosols with a base saturation of $18 \%$. Average air temperature at Villingen is $6.3^{\circ} \mathrm{C}$ with an annual bulk precipitation of $1330 \mathrm{~mm}$ (19881995) (Armbruster, 1998). Soils in the catchment Schluchsee are dominated by haplic Podzols with extremely low base saturation $(<4.1 \%)$ and $\mathrm{pH}\left(\mathrm{CaCl}_{2}\right)<4.3$ down to $1 \mathrm{~m}$ depth. Average annual precipitation at Schluchsee between 1988 and 1996 was $1870 \mathrm{~mm}$ with an average air temperature of $4.4^{\circ} \mathrm{C}$ (Armbruster, 1998).

Average total deposition at the sites investigated is presented in Table 1 (for calculation of total deposition see below).

Table 1. Average total deposition of $\mathrm{S}$ and $\mathrm{N}$ in $\mathrm{mmol}_{\mathrm{c}}$ $\mathrm{m}^{-2} \mathrm{yr}^{-1}$ at the catchments (arithmetic means of 1988-1995).

\begin{tabular}{llll}
\hline Catchment & $\mathrm{SO}_{4}$ & $\mathrm{NH}_{4}$ & $\mathrm{NO}_{3}$ \\
\hline Lange Bramke & 183 & 112 & 97 \\
Lehstenbach & 223 & 106 & 76 \\
Markungsgraben & 128 & 92 & 75 \\
Metzenbach & 67 & 55 & 46 \\
Villingen & 59 & 54 & 38 \\
Schluchsee & 58 & 44 & 37 \\
\hline
\end{tabular}


A detailed site description as well as a description of sampling technique and analytical methods is given by Manderscheid and Göttlein (1995) for the Lehstenbach catchment (Fichtelgebirge), LfW (1994) for the catchments Metzenbach and Markungsgraben, by Armbruster (1998) for Villingen and Schluchsee (Black Forest) and by Schmidt (1997) for the Bramke area (Lange Bramke, Steile Bramke and Dicke Bramke catchments in the Harz mountains). Note that within the Bramke area, deposition and throughfall measurements are carried out only in the Lange Bramke catchment.

Most time series started in 1987/1988 and ended in 1999 with the exception of the sites within the Bramke area in the Harz mountains (measurement period 1975-1999 at Lange Bramke and Dicke Bramke; 1983-1999 at Lange Bramke spring and 1987-1999 at Steile Bramke) and the two sites Villingen and Schluchsee (Black Forest, measurement period 1987-1995/1996). Measurements of concentrations in bulk precipitation, throughfall and runoff were carried out weekly (Villingen, Schluchsee, note that starting in 1990 weekly precipitation and throughfall samples were combined to monthly bulk samples before analysis), fortnightly (Lehstenbach, Markungsgraben, Metzenbach) or monthly (Bramke area, weekly samples, monthly analyses).

Trend analysis was undertaken with the Seasonal Kendall Test, a non-parametric method in which data are grouped into seasonal (monthly) blocks, and ranked to identify monotonic long-term trends. The significance limit was set to $\mathrm{p}<0.05$, and trend slopes were estimated as the median concentration change between years for all seasonal blocks. The trend statistic $\mathrm{T}$ gives decrease (negative values) or increase (positive values) in $\mu \mathrm{mol}_{\mathrm{c}} \mathrm{l}^{-1} \mathrm{yr}^{-1}$. A detailed description of statistical methods is given in Evans et al. (2001).

\section{CALCULATION OF FLUXES AND BUDGETS}

Input fluxes with bulk precipitation were calculated as concentration times precipitation amount. Total deposition for all elements with the exception of $\mathrm{SO}_{4}$ and $\mathrm{N}$ was calculated according to Eqn. (1) (Ulrich, 1994):

$$
\mathrm{TD}_{\text {element }}=\mathrm{ID}_{\mathrm{Na}} / \mathrm{BP}_{\mathrm{Na}} * \mathrm{BP}_{\text {element }}
$$

with $\mathrm{TD}=$ flux of total deposition, ID = interception deposition $\left(\mathrm{ID}_{\mathrm{Na}}=\mathrm{TF}_{\mathrm{Na}}-\mathrm{BP}_{\mathrm{Na}}\right), \mathrm{BP}=$ flux of bulk precipitation and $\mathrm{TF}=$ flux of throughfall.

Several authors argue that $\mathrm{SO}_{4}$ deposition with throughfall describes adequately patterns of total deposition, because of the low exchange between the forest canopy and $\mathrm{S}$ species
(Matzner, 1988; Ulrich, 1994; Lovett et al., 1997). Thus, for total deposition of $\mathrm{SO}_{4}$, throughfall flux values were taken. For all other ions, Eqn. (1) was used for the calculation of total deposition.

Output fluxes from the catchment with run-off were calculated according to:

yearly element flux $=\left(\sum\right.$ element flux at measurement day $)$ * yearly discharge / $\sum$ discharge rate at measurement days

Data of yearly output fluxes in Villingen and Schluchsee were taken from Armbruster (1998) who calculated fluxes according to Likens et al. (1977), where the sum of water fluxes of a measurement period were multiplied with the arithmetic means of element concentrations at the start and end point of the measurement period ("period-weightedsample" method). Yearly element fluxes were calculated by summation of fluxes of all measurement periods. Comparative studies by Brahmer (1990) showed good agreements with fluxes calculated from weekly, timeproportional bulk samples.

For the calculation of budgets, output fluxes were subtracted from input fluxes. Thus, positive budgets indicate accumulation while negative budgets indicate net loss from the catchments.

When evaluating element fluxes in forested catchments, the quantification of water fluxes is crucial. At Markungsgraben and Schluchsee measurement of precipitation amount is connected to high errors because of steep slopes and relatively high contribution of snow to total annual precipitation (up to $40 \%$ ). Thus, element fluxes in total deposition are most likely to be underestimated in these catchments (see Armbruster, 1998). At Metzenbach and Villingen part of the run-off leaves the catchment below ground. Armbruster (1998) measured and calculated the contribution of subterranean element fluxes via water supply wells to total catchment output for Villingen which is considered in the output fluxes presented. Subterranean element fluxes were calculated from measured groundwater concentrations and water fluxes obtained from two water supply wells inside the catchment. Subterranean water flux contributed $15 \%$ to the total catchment output, base cations between $17 \%-25 \%, \mathrm{H}$ and $\mathrm{Al} 7$ and $6 \%$, respectively and $\mathrm{SO}_{4}$, chloride $(\mathrm{Cl})$ and $\mathrm{NO}_{3} 23,16$ and $25 \%$, respectively (average values for 1988-1995) (Armbruster, 1998).

\section{METHODS TO EVALUATE TRENDS IN BIOLOGICAL RECOVERY}

To evaluate the status and trends in biological recovery the Bavarian Water Management Agency monitored 
macroinvertebrates and diatom communities between 1989 and 1996 in the Fichtelgebirge, the Spessart and the Bavarian Forest (investigated streams Eger, Speckkahl, Große Ohe, respectively; LfW, 1999). In the Harz mountains the stream Dicke Bramke was monitored for macroinvertebrates and diatom communities between 1988 and 1994 (LfW, 1998). With the help of macroinvertebrate communities the streams were classified in four categories of acidity as SZKL I to IV $($ SZKL $=$ Säurezustandsklassen $=$ acidity classes $)$, which refer to not acid, low acidity, periodically acid and permanently acid. A detailed description of the sampling routine, calculation of acidity categories and evaluation of trends is given in LfW (1999).

\section{Results and discussion}

\section{TRENDS IN CONCENTRATIONS}

When discussing reversibility of acidification, $\mathrm{SO}_{4}$ dynamics play a crucial role because $\mathrm{SO}_{4}$ is the dominant anion in many soil solutions and waters. Sulphate leaching from soils causes cation leaching and is thus a key process in the acidification of soils and waters. Trends were calculated for total and estimated non-marine $\mathrm{SO}_{4}$. Because of the relatively large distance from the sea, contribution of sea salt is very low in all catchments. Thus, trends for estimated non-marine $\mathrm{SO}_{4}$ and total $\mathrm{SO}_{4}$ are very similar. Because estimation of non-marine $\mathrm{SO}_{4}$ is always connected to an unknown error (especially in areas with high dust emissions from industry), concentrations of total $\mathrm{SO}_{4}$ are presented and discussed. Within the German catchments there was generally a significant decrease in $\mathrm{SO}_{4}$ concentrations in throughfall and bulk precipitation (Table 2). Rather small changes in the $\mathrm{SO}_{4}$ concentrations in throughfall and bulk precipitation where observed, however, in the Villingen and Schluchsee catchments in the Black Forest, an area that receives low deposition input (Table 1). In the case of throughfall, this change was significant $(\mathrm{p}<0.053$; Table 2) even though extreme values and peak frequency are clearly decreasing (data not shown, see Prechtel et al., 2001; Armbruster, 1998).

Table 2. Trends of statistics from the Kendall tau test in $\mu \mathrm{mol}_{\mathrm{c}}{ }^{-1} \mathrm{yr}^{-1}$ for throughfall (TF) and run-off (Run) concentrations (significance level $\mathrm{p}<0.05$ ). Trends of bulk precipitation are given in brackets if significantly different from TF. NS $=$ not significant. Trends for base cations were calculated as ( $\mathrm{Ca}, \mathrm{Mg}, \mathrm{K}, \mathrm{Na})$. ANC = calculated as Reuss and Johnson (1986). Note that $\mathrm{NH}_{4}$ in runoff is mainly below detection limit.

\begin{tabular}{|c|c|c|c|c|c|c|c|c|c|c|c|c|c|}
\hline \multirow[b]{2}{*}{ Catchment } & \multicolumn{2}{|c|}{ Base Cations } & \multirow{2}{*}{$\begin{array}{l}A l \\
\text { Run }\end{array}$} & \multirow{2}{*}{$\begin{array}{l}p H \\
T F\end{array}$} & \multirow[b]{2}{*}{ Run } & \multicolumn{2}{|l|}{$A N C$} & \multicolumn{2}{|c|}{ Sulphate } & \multirow{2}{*}{$\begin{array}{l}\mathrm{NH}_{4} \\
\mathrm{TF}\end{array}$} & \multirow[b]{2}{*}{ Run } & \multirow{2}{*}{$\begin{array}{l}\mathrm{NO}_{3} \\
\mathrm{TF}\end{array}$} & \multirow[b]{2}{*}{ Run } \\
\hline & $T F$ & Run & & & & $T F$ & Run & $T F$ & Run & & & & \\
\hline Villingen & NS & NS & NS & +0.06 & NS & NS & NS & $\begin{array}{l}\text { NS } \\
(-1.6)\end{array}$ & -3.6 & NS & NS & NS & +0.2 \\
\hline Schluchsee & $\begin{array}{l}\text { NS } \\
(-1.4)\end{array}$ & NS & NS & $\begin{array}{l}\text { NS } \\
(-0.3)\end{array}$ & NS & +3.0 & NS & $\begin{array}{l}\text { NS } \\
(-1.4)\end{array}$ & -1.1 & $\begin{array}{l}\text { NS } \\
(-1.4)\end{array}$ & NS & NS & NS \\
\hline Lange Bramke & -18.2 & $\mathrm{NS}^{1}$ & - & +0.05 & NS & +6.1 & NS & -9.9 & +1.2 & NS & - & NS & $\mathrm{NS}^{2}$ \\
\hline $\begin{array}{l}\text { Lange Bramke } \\
\text { spring }\end{array}$ & - & -3.3 & -17.5 & - & NS & - & NS & - & -2.2 & - & - & - & -3.1 \\
\hline Dicke Bramke & - & -10.6 & -2.7 & - & NS & - & -3.2 & - & -4.8 & - & - & - & NS \\
\hline Steile Bramke & - & -25.6 & - & - & NS & - & NS & - & -6.7 & - & - & - & -9.2 \\
\hline Markungsgraben & -13.8 & $-\mathrm{NS}^{3}$ & $\mathrm{NS}^{3}$ & +0.07 & $\mathrm{NS}^{3}$ & NS & $\mathrm{NS}^{3}$ & -13.7 & $\mathrm{NS}^{3}$ & -2.3 & $\mathrm{NS}^{3}$ & -5.4 & $\mathrm{NS}^{3}$ \\
\hline Metzenbach & -12.3 & -4.6 & NS & $\begin{array}{l}\text { NS } \\
(+0.04)\end{array}$ & 0.06 & NS & NS & -4.4 & -2.7 & NS & 0.1 & NS & -1.7 \\
\hline Lehstenbach & -20.8 & NS & NS & 0.07 & NS & - & NS & -34.0 & -5.2 & $\begin{array}{l}-4.5 \\
(\mathrm{NS})\end{array}$ & NS & NS & NS \\
\hline $\begin{array}{l}{ }^{1} \text { break in Jan- } 89 \mathrm{~b} \\
{ }^{2} \text { break in Jan- } 84 \mathrm{~b} \\
{ }^{3} \text { stream trends } M a\end{array}$ & $\begin{array}{l}\text { efore: + } \\
\text { efore: + } \\
\text { rkungsg }\end{array}$ & $\begin{array}{l}-2.1 \text {, aft } \\
-3.1 \text {, aft } \\
\text { graben g }\end{array}$ & $\begin{array}{l}\text { er }-8.4 \text {. } \\
\text { er }-1.7 \\
\text { jiven up }\end{array}$ & I & & & & & & & & & \\
\hline
\end{tabular}


In response to decreased deposition levels, seven out of the nine streams investigated had significant decreasing $\mathrm{SO}_{4}$ concentrations (Table 2). Sulphate was still the dominant anion, however, in the streams of all investigated catchments (average \% $\mathrm{SO}_{4}$ of $\sum\left\{\mathrm{Cl}, \mathrm{NO}_{3}, \mathrm{SO}_{4}\right\}=37 \%$ in Markungsgraben, $53 \%$ in Lehstenbach, $60 \%$ in Schluchsee, $66-70 \%$ in the streams of the Bramke area, $70 \%$ in Metzenbach and $75 \%$ in Villingen). Thus, even though $\mathrm{SO}_{4}$ deposition has decreased significantly for the last two decades, the overall decrease in $\mathrm{SO}_{4}$ concentrations in streams of the lower mountain ranges in Germany was minor. This delayed response was caused by a release of previously stored inorganic and organic soil S (for a detailed discussion of S dynamics and trends see Prechtel et al., 2001).

In addition to decreasing $\mathrm{SO}_{4}$ deposition, trends in $\mathrm{pH}$ and acid neutralising capacity (ANC) in bulk precipitation and throughfall were increasing slightly or remained unchanged (Table 2). Streams of the catchments investigated were acid and had $\mathrm{pH} \leq 6.5$ most of the year with no temporal
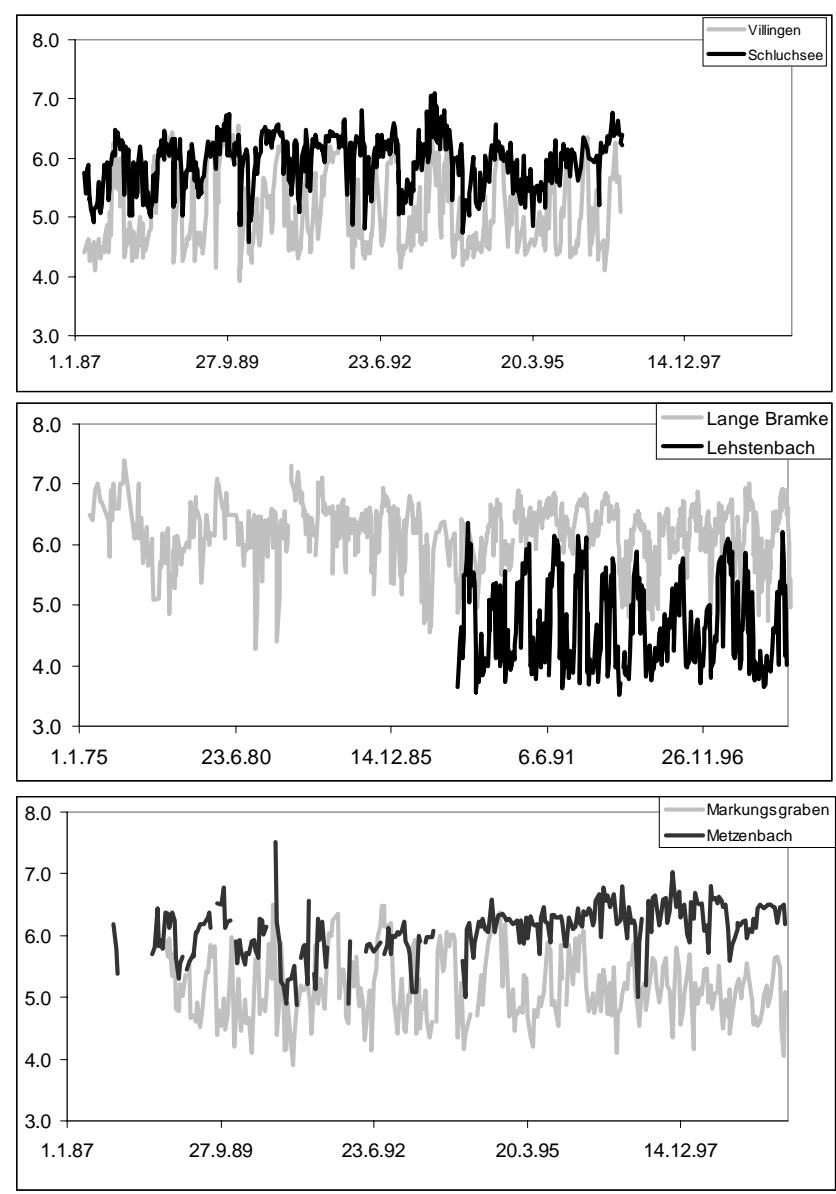

Fig. 2. $p H$ in stream waters trend (Fig. 2). The reason for the constant acidity in the streams and the delayed increase of $\mathrm{pH}$ can be attributed to the buffering capacity of the soils. All soils investigated have received considerable loads of acidity in the past (Table 1) and the stored $\mathrm{SO}_{4}$ and acidity will be released under the currently low deposition regime.

Average ANC in streams (ANC as defined by Reuss and Johnson, 1986; levels calculated as arithmetic mean values) ranged from approximately $75 \mu \mathrm{mol}_{\mathrm{c}} \mathrm{l}^{-1}$ at Lange Bramke,

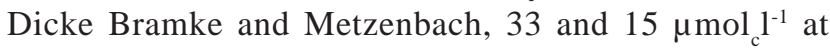
Villingen and Schluchsee, respectively, around $0 \mu \mathrm{mol}_{c} \mathrm{c}^{-1}$ at Markungsgraben, $-50 \mu \mathrm{mol}^{1} \mathrm{l}^{-1}$ at Lehstenbach to an average of $-140 \mu_{\mathrm{mol}_{\mathrm{c}} \mathrm{l}^{-1}}$ at Lange Bramke spring (Fig. 3, note that of the Bramke area only Lange Bramke is shown). At Steile Bramke, which was limed in 1989, average ANC was around $100 \mu \mathrm{mol}_{\mathrm{c}} \mathrm{l}^{-1}$ before liming (1987 to 1989) and $180 \mu \mathrm{mol}_{\mathrm{c}} \mathrm{l}^{-1}$ thereafter (1989-1999, data not shown). According to the Kendall tau test statistics, none of the streams had significantly increasing ANC (Table 2, Fig. 3). The stream Dicke Bramke within the Bramke area (Harz)
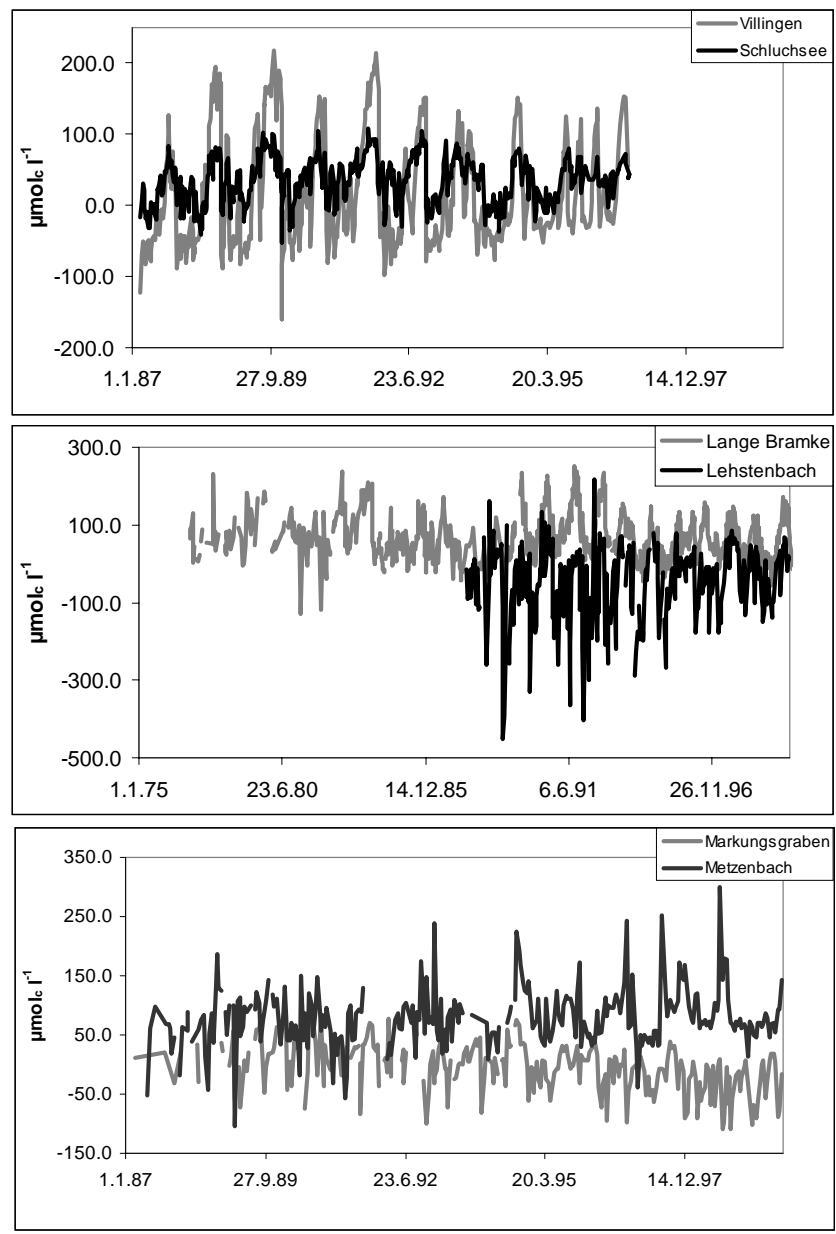

Fig. 3. Acid neutralising capacity (ANC) of streams as defined by Reuss and Johnson (1986) in umol $^{l^{-1}}$ 
even had significantly decreasing ANC (Table 2). Total Al concentration in streams responded similarly to $\mathrm{pH}$ and ANC. Kendall tau trend statistics (Table 2) and average stream concentrations of $\mathrm{Al}$ (Fig. 4) indicated no decline except for Lange Bramke spring and Dicke Bramke.

Although trends are not significant, a decrease in concentrations of extreme values and peak frequency is noticeable (Figs. 2, 3 and 4). The decrease in extreme values (both concentrations and frequencies) is clearly an indication of improved water quality and life conditions for the aquatic fauna. Thus, even though the decrease in acid deposition is so far not reflected in a major acidification reversal, the first signs of improvement are detectable.

With a reduction in particulate emissions throughout Europe and North America, base cation deposition has been reduced in many forest ecosystems (Driscoll et al., 1989; Hedin et al., 1994; Meesenburg et al., 1995; Alewell et al., 2000a;b). This is clearly reflected in the throughfall and bulk deposition trends of the investigated sites. At most sites the base cation concentrations in bulk precipitation and
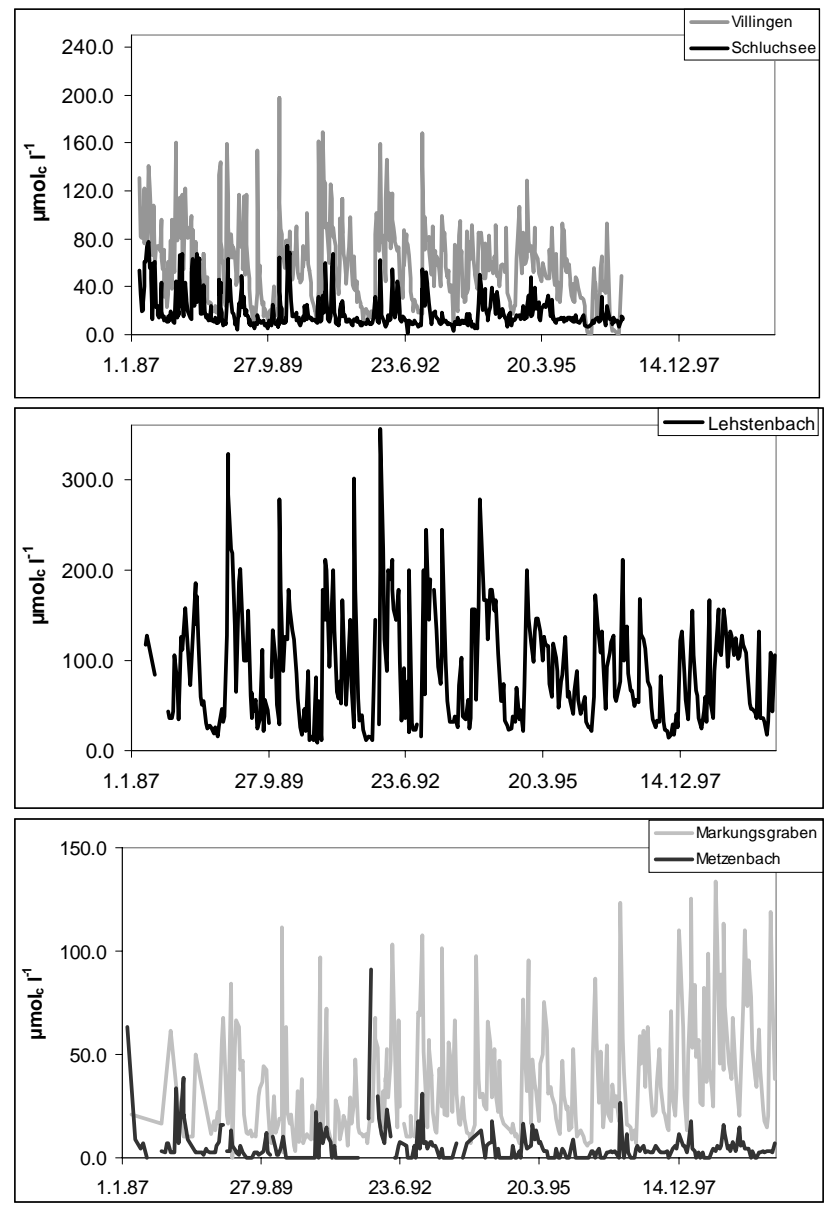

Fig. 4. Aluminum concentrations in stream waters in $\mu \mathrm{mol}_{c} \mathrm{l}^{-1}$ throughfall have decreased significantly (with the exception of the Villingen and Schluchsee sites in the Black Forest, Table 2). Parallel to the decrease in base cation concentration in the input to the catchments, four out of nine streams responded with a significant decline in base cation concentrations of stream water. At Steile Bramke, a decrease in base cation concentration in the stream occurred even though the catchment was limed. A general assessment of change in base cation concentrations in streams is not easy to make. A decrease in base cation concentrations in streams causes a delay in the increase of ANC (because ANC is calculated as the sum of base cations minus the sum of acid anions). On the other hand, continued high stream concentrations with decreasing input concentrations point to a continued high base cation leaching from soils (for a discussion of fluxes see below).

Inorganic $\mathrm{N}$ plays an important role in the acidification of soil solution and stream waters, and has often been underestimated in the past because of the capability of most terrestrial ecosystems to retain deposited N (Sullivan et al., 1997). A major part of the deposited $\mathrm{NH}_{4}$ will be nitrified in acid forest soils, thus producing acidity within the soil (2 moles $\mathrm{H}$ per mole $\mathrm{NH}_{4}$ ). Furthermore, leaching of $\mathrm{Al}, \mathrm{H}$ and nutrient cations has been shown to be correlated to $\mathrm{N}$ saturation of soils (Currie et al., 1999). With the exception of Markungsgraben (Bavarian Forest) none of the sites decreased in either $\mathrm{NH}_{4}$ or $\mathrm{NO}_{3}$ concentration in throughfall and bulk precipitation (Table 2, note that at Markungsgraben bark beetle infestation caused dieback of the spruce stands in 1997 resulting in a decrease of interception deposition). Correspondingly, there are no clear trends in the $\mathrm{NO}_{3}$ concentration of the streams. $\mathrm{NO}_{3}$ concentrations decreased slightly in streams in Steile Bramke, Lange Bramke spring and Metzenbach. On average, over the measurement period, $\mathrm{NO}_{3}$ contributed to $3 \%$ of "acid anions" (defined as $\sum \mathrm{Cl}$, $\mathrm{NO}_{3}, \mathrm{SO}_{4}$ ) in Villingen, $10 \%$ in Lehstenbach and Metzenbach, 10-16\% in the streams of the Bramke area, 25\% in Schluchsee and 53\% in Markungsgraben (average values, no trends were noticeable with the exception of Markungsgraben as discussed below). Even though $\mathrm{SO}_{4}$ is still the dominant anion in the streams of all catchments, $\mathrm{NO}_{3}$ will become more and more important with an expected acidification reversal due to reduction of $\mathrm{SO}_{4}$ deposition (for a discussion of the overall $\mathrm{N}$ dynamics on a European scale see Wright et al., 2001).

A special situation occurs in the Markungsgraben catchment. The catchment is located within the Bavarian Forest National Park which has the management aim of "leaving nature alone". Starting in 1996, mass propagation of a bark beetle (Ips typographus L.) resulted in the total destruction of the spruce stands, which covered $81 \%$ of the 
catchment area in 1999 (for details see Zimmermann et al., 2000). The bark beetle infestation caused a reduction in $\mathrm{N}$ input (due to deforestation and thus lower interception deposition) and a dramatic increase in $\mathrm{N}$ leaching (for budgets see below). Statistical analysis indicated a break in trend calculations in 1996 with a decline in ANC (Kendal tau statistics for trends from Jan- 96 and onwards $\mathrm{T}=-3.6$ $\mu \mathrm{mol}_{\mathrm{c}} \mathrm{l}^{-1} \mathrm{yr}^{-1}$; not signifcant) and a sharp increase in $\mathrm{NO}_{3}(\mathrm{~T}=$ $\left.30 \mu_{\mathrm{mol}_{\mathrm{c}}}{ }^{-1} \mathrm{yr}^{-1} ; \mathrm{p}<0.052\right)$, and $\mathrm{Al}\left(\mathrm{T}=69 \mu_{\mathrm{mol}_{\mathrm{c}}}{ }^{-1} \mathrm{yr}^{-1}\right.$, not significant). Note, that trends were not significant due to the relatively short measurement period after the infestation (1996-1999). The example of Markungsgraben demonstrates that ecosystems change relatively quickly from functioning as sinks for $\mathrm{N}$ to extreme sources when environmental changes or disturbances occur. In Markungsgraben, however, $\mathrm{NO}_{3}$ was already the dominant anion in run-off before the bark beetle infestation (approximately $50 \%$ of $\sum \mathrm{Cl}, \mathrm{NO}_{3}, \mathrm{SO}_{4}$ up to 1995 and increasing to $75 \%$ in 1998).

\section{TRENDS IN FLUXES AND BUDGETS}

A common tool for assessing the accuracy of element budgets in ecosystems is the evaluation of $\mathrm{Cl}$ budgets, because $\mathrm{Cl}$ is considered to be relatively inert to internal cycling within the ecosystems. Element budgets for $\mathrm{Cl}$ (Fig. 5) are generally well balanced with the exception of a negative budget in Lehstenbach (stream water output > input with total deposition) which was due to high additions of road salt on the roads during winter periods (Lehmann, 2000).

Under the decreasing $\mathrm{SO}_{4}$ deposition regime of the last two decades, catchments have changed from a net retention to a net loss of $\mathrm{SO}_{4}$ since the beginning of the 1990s (Fig. 5). Thus, with the decrease in deposition, previously stored $\mathrm{SO}_{4}$ is currently released from the soils into the streams. Since the leaching of anions is always connected to cation leaching, the release of $\mathrm{SO}_{4}$ delays a reversal of freshwater acidification due to leaching of $\mathrm{H}, \mathrm{Al}, \mathrm{Fe}$, and $\mathrm{Mn}$ (for a detailed discussion of $\mathrm{S}$ dynamics and its influence on freshwater acidification see Prechtel et al., 2001).

With regard to $\mathrm{N}$ budgets, no trends were observed for $\mathrm{NH}_{4}$ or $\mathrm{NO}_{3}$. With the exception of Markungsgraben, none of the catchments showed a net loss of $\mathrm{N}$ from the catchment. At Markungsgraben, average retention of total $\mathrm{N}$ was $70 \mathrm{mmol}_{\mathrm{c}} \mathrm{m}^{-2} \mathrm{yr}^{-1}$ until 1997 (average $\mathrm{NO}_{3}$ loss until $1996=$ $\left.40 \mathrm{mmol}_{\mathrm{c}} \mathrm{m}^{-2} \mathrm{yr}^{-1}\right)$. In 1998, a sudden net loss of total $\mathrm{N}$ $\left(180 \mathrm{mmol}_{\mathrm{c}} \mathrm{m}^{-2} \mathrm{yr}^{-1}\right.$ with a $\mathrm{NO}_{3}$ leaching of $270 \mathrm{mmol}_{\mathrm{c}} \mathrm{m}^{-2}$ $\mathrm{yr}^{-1}$ ) was induced by mass propagation of bark beetles.

When discussing the development of acidification reversal, the dynamic of base cations is of major importance because of the effect on ANC. Furthermore, a significant leaching of base cations will lead to a decrease in base saturation of soils and may cause problems with forest nutrition (Malmer, 1976; Ulrich et al., 1980; Baes and McLaughlin, 1984; BML, 1997; Riek and Wolff, 1998). Despite the significant decrease in acid deposition, leaching of base cations did not decrease. All catchments investigated showed continued high cation leaching, and a general increase in net release from the ecosystems is observed (Fig. $6)$.

A similar dynamic has been shown for other sites in Germany (the Solling, Wesselink et al., 1995), Norway (Birkenes, Christophersen et al., 1990) and the United States (Hubbard Brook Experimental Forest, Driscoll et al., 1989). Thus, even though base cation concentrations in streams have been declining, net losses from ecosystems are increasing due to the combination of significant decrease in base cation deposition and continued high leaching of anions. A gradual loss of base cations from soils is a natural feature of weathering and pedogenesis. Loss of base cations, however, can be accelerated by acid rain, by forest regrowth following harvest removals and by declining inputs of base cations from atmospheric deposition (Johnson et al., 1991; Yanai et al., 1999). Thus, an increased loss in base cations has important implications for forest managers, water authorities and policy makers. Low harvesting intensity and careful selection of tree species can lead to tighter element cycles, thus decreasing acidification and leaching of base cations (Kreutzer, 1994). Lenz et al. (1994) pointed out that the harvest removal in the Fichtelgebirge mountains led to an acid load within the soil comparable to the anthropogenic acid deposition. Additionally, liming or amelioration of soils can improve base saturation. In many German forest ecosystems soils have to be improved in order to carry out regeneration programmes successfully or to rebuild more natural forest ecosystems (Raben et al., 2000). Since all catchments investigated are representative regions for drinking water supply, water authorities have to calculate the treatment of waters, namely deacidification and purification from $\mathrm{Al}, \mathrm{Fe}$ and $\mathrm{Mn}$ probably for decades to come.

Because of the high errors connected with the calculations, it might be argued that budget calculations for whole catchments are insufficient evidence to prove that pools of soil base cations are decreasing. Trends in element soil pools, however, especially in base cations, are difficult to detect from direct soil analysis due to constraints regarding spatial heterogeneity, sampling techniques (e.g. resampling of the same spots and horizons, retaining the same methods over time) and slow development of temporal trends (Yanai et al., 1999). A decrease in soil base cation pools has been 

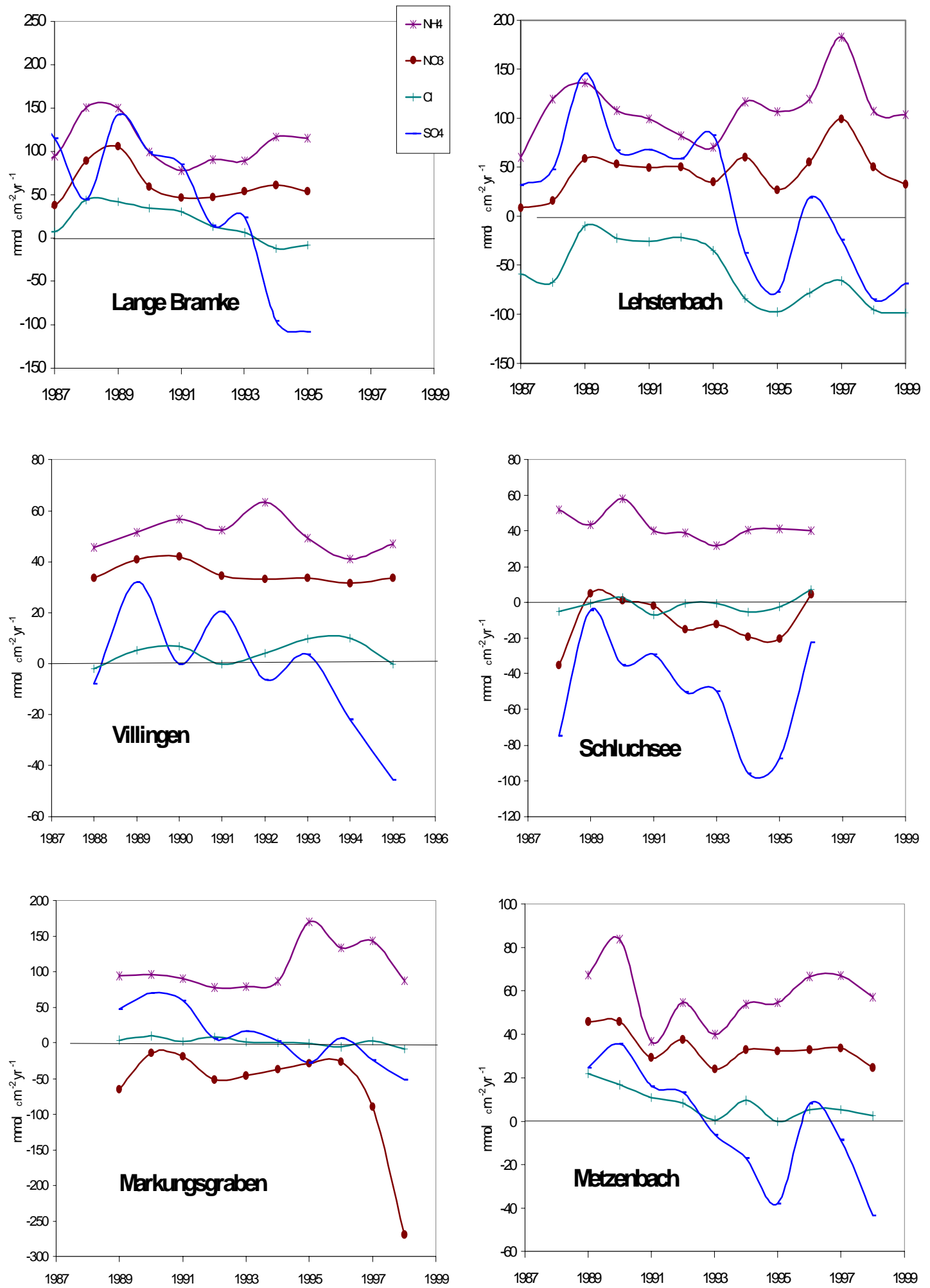

Fig. 5. Element budgets ( mmol $\left._{c} m^{-2} y r^{-1}\right)$ for $\mathrm{NH}_{4}, \mathrm{NO}_{3}, \mathrm{Cl}$ and $\mathrm{SO}_{4}$ calculated as total deposition minus run-off flux

shown by Wesselink et al. (1995) for the Solling soil in Germany. Nevertheless, constraints regarding flux/budget calculations should not be ignored. Thus, conclusions from budget calculations in this study are based on trends in budgets (not absolute numbers) and only if supported by trends in concentrations. 


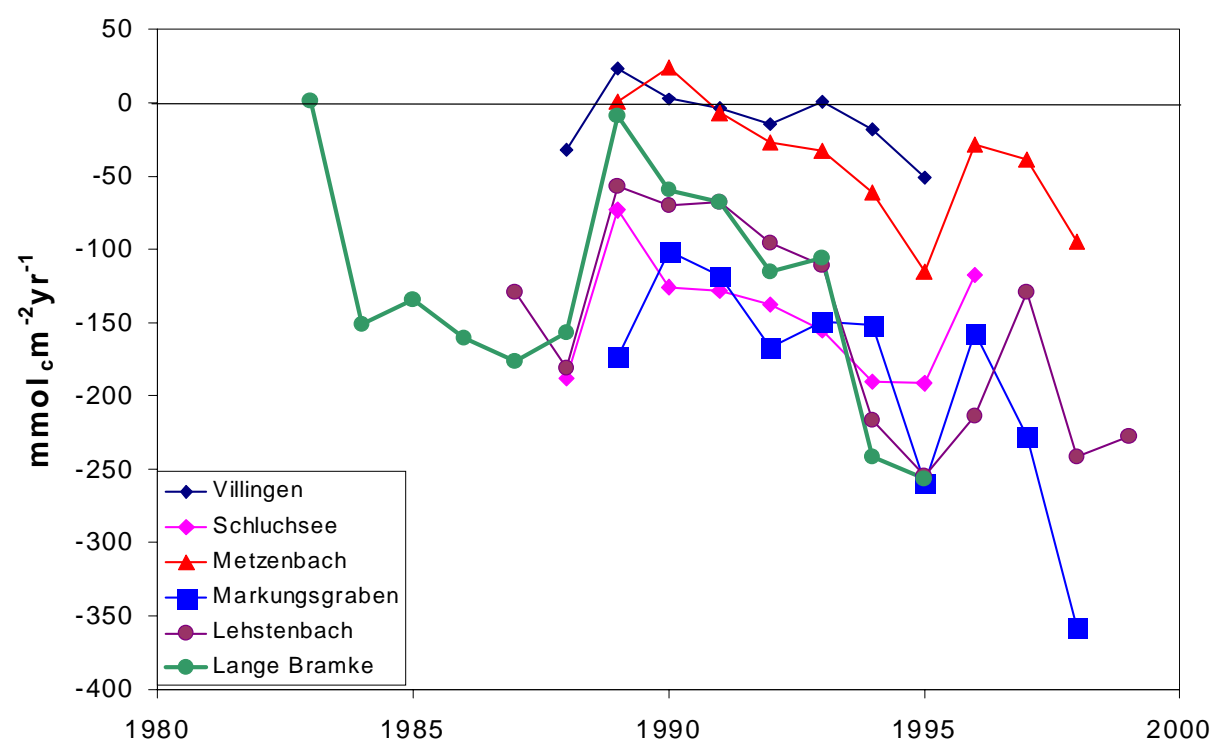

Fig. 6. Element budgets for sum of base cations ( $\mathrm{C} \mathrm{Ca}, \mathrm{Mg}, \mathrm{Na}, \mathrm{K})$ in $\mathrm{mmol}_{\mathrm{c}} \mathrm{m}^{-2} \mathrm{yr}^{-1}$ calculated as total deposition minus run-off flux.

\section{BIOLOGICAL RECOVERY}

To judge the biological recovery in the Bavarian Forest data from the Große Ohe were assessed (note that Markungsgraben is a subcatchment of Große Ohe). Macroinvertebrates were classified according to the acidity category II - III (= between low acidity to periodically acid) with no clear trend between 1983 and 1996 (LfW, 1999). No acid sensitive species were found in the region, however, species from the genus Baetis, which are sensitive to acidity and were missing during the 1980 s, were re-occurring in the early 1990s. Considering the development of the diatom communities, a decline in the abundance of Eunotia exigua, which is known to be acid tolerant, may be interpreted as a slight biological recovery (LfW, 1999). Biological recovery in three Bavarian Forest lakes (Schaumburg, 2000) was not observed, however, even though lake water chemistry showed signs of an acidification reversal (decrease of $\mathrm{SO}_{4}$, $\mathrm{Al}$, and $\mathrm{NO}_{3}$ concentrations and increased $\mathrm{pH}$ ).

Within the Fichtelgebirge area the stream Eger was investigated for trends in biological communities (Lehstenbach is a subcatchment of the Eger catchment). Macroinvertebrate communities improved from being between SZKL III to IV in the late 80s to SZKL III in the early 90s. Diatom communities, however, showed no trend. LfW (1999) pointed out, that the Eger stream drains an area which is protected from extremes of acid deposition by the mountains Schneeberg and Ochsenkopf, which function as a rain shield and so promote lower total deposition to the area. Thus, the slight improvement in acid status determined in this catchment is in contrast to other catchments investigated within the Fichtelgebirge mountains, most of which still show a general deterioration in biological status (LfW, 1999).

The stream Speckkahl in the Spessart mountains was investigated between 1994 and 1996. Macroinvertebrate and diatom communities point to an acidity category between low acidity to periodically acid (SZKL II - III; LfW, 1999) with no trends.

At Dicke Bramke, macroinvertebrate communities fluctuated between SZKL II and IV between 1988 and 1994. The occurence of Helodes sp. and Odontocerum ablicorne in the 1990s may indicate a beginning of biological recovery. Diatom communities indicated low acidity status with no trend throughout the measurement period (LWF, 1998).

\section{Conclusions}

Stream $\mathrm{SO}_{4}$ concentrations in the low mountain ranges of Germany are generally decreasing due to reduced anthropogenic atmospheric $\mathrm{SO}_{4}$ deposition. This is so far not reflected in an acidification reversal, as indicated by continuing low ANC and low $\mathrm{pH}$ of stream waters. First signs of reversibility of acidification in freshwater systems are indicated by decrease in concentrations and frequency of extreme values in $\mathrm{ANC}, \mathrm{pH}$, and $\mathrm{Al}$. Net loss of base cations from the ecosystems is increasing due to decreased base cation deposition with continued high cation leaching. An increase of base cation loss from soils might be interpreted as an increase in soil acidification.

Regarding $\mathrm{N}$ dynamics, no major changes are seen in 
either deposition or stream water output. Furthermore, as indicated by the data from the catchment Markungsgraben, disturbance of ecosystem balance by, for example, bark beetle infestation will lead to increased $\mathrm{N}$ and $\mathrm{Al}$ leaching which causes temporarily higher requirement on water treatment plants.

With respect to biological communities, no major recovery is observed yet. However, small changes in population dynamics might be interpreted as the first signs of recovery.

A significant delay in recovery from acidification in the low mountain ranges of Germany has important implications for water authorities, forest managers and policy makers. Forest management is still confronted with the need for frequent liming as well as consideration of sustainable management to avoid base cation depletion of soils and subsequent nutrient deficiencies in the trees. Water authorities should be aware that acidification reversal and recovery of aquatic systems in the area will be delayed, potentially for decades. Even catchment liming results in a very delayed response of stream water in the catchments with deeply weathered soils as demonstrated at the Steile Bramke. Policy makers should consider that $\mathrm{N}$ deposition has to be reduced considerably in order to limit cation depletion from soils, risks connected to increasing $\mathrm{N}$ saturation and further soil and water acidification.

\section{Acknowledgements}

This project was financially supported by the Commission of European Communities RECOVER:2010 project (EVK1CT-1999-00018) and the German Ministry of Education and Research, grant no. PT BEO 51-0339476.

\section{References}

Alewell, C., Manderscheid, B., Gerstberger, P. and Matzner, E., 2000a. Effects of reduced atmospheric deposition on soil solution chemistry and elemental contents of spruce needles in NE-Bavaria, Germany. J. Plant Nutr. Soil Sci., 163, 509-516.

Alewell, C., Manderscheid, B., Meesenburg, H. and Bittersohl, J., 2000b. Is acidification still an ecological threat? Nature, 407, 856-857.

Armbruster, M., 1998. Zeitliche Dynamik der Wasser- und Elementflüsse in Waldökosystemen. Freiburger Bodenkundl. Abhandl., 38, 1-301.

Baes, C.F. and McLaughlin, S.B., 1984. Trace elements in tree rings: evidence of recent and historical air pollution. Science, 224, 494-497.

Baker, J.P. and Schofield, C.L., 1982. Aluminum toxicity to fish in acidic waters. Water Air Soil Pollut., 18, 289-309.

BML, 1997. Deutscher Waldbodenbericht, 1996. Bundesministerium für Ernährung Landwirtschaft und Forsten, Bonn, $157 \mathrm{pp}$.

Brahmer, G., 1990. Wasser- und Stoffbilanzen bewaldeter Einzugsgebiete im Schwarzwald unter besonderer
Berücksichtigung naturräumlicher Ausstattungen und atmogener Einträge. Freiburger Bodenkundl. Abhandl., 25, 1-195.

Christen, Y., 2000. Oxidative stress and Alzheimer disease. Amer. J. Clin. Nutr., 71, 621-629.

Christophersen, N., Robson, A., Neal, C., Whitehead, P.G., Vigerust, B. and Henriksen, A., 1990. Evidence for long-term deterioration of streamwater chemistry and soil acidification at the Birkenes catchment, southern Norway. J. Hydrol., 116, 6376.

Cronan, C.S. and Grigal, D.F., 1995. Use of calcium/aluminum ratios as indicators of stress in forest ecosystems. J. Environ. Qual., 24, 209-226.

Currie, W.S., Aber, J.D. and Driscoll, C.T., 1999. Leaching of nutrient cations from the forest floor: effects of nitrogen saturation in two long-term manipulations. Can. J. Forest Res., 29, 609-620.

De Wit, H.A., 2000. Solubility controls and phyto-toxicity of aluminum in a mature Norway spruce forest. Agricultural University of Norway, Ås. Doctor Scientiarum Theses, 14, 136.

Driscoll, C.T., Bisogni, J.J. and Schofield, C.L., 1980. Effect of aluminum speciation on fish in dilute acidified waters. Nature, 248, 161-164.

Driscoll, C.T., Likens, G.E., Hedin, L.O., Eaton, J.S. and Borman, F.H., 1989. Changes in the chemistry of surface waters. Environ. Sci. Technol., 23, 137-143.

Erisman, J.W., de Vries, W. and Müller-Edzards, C., 1997. In: Ten years of Monitoring Forest Condition in Europe. Studies on Temporal Development, Spatial Distribution and Impacts of Natural and Anthropogenic Stress Factors. Technical Background Report of the Convention on Long Range Transboundary Air Pollution International Cooperative Programme on Assessment and Monitroing of Air Pollution Effects on Forests, C. Müller-Edzards, W. de Vries and J.W. Erisman (Eds.), 377-386. Federal Research Centre for Foresty and Forest Products. EC-UN/ECE Brussels, Geneva.

Evans, C.D., Cullen, J.M., Alewell, C., Marchetto, A., Moldan, F., Kopácek, J., Prechtel, A., Rogora, M., Vesely, J. and Wright, R.F., 2001. Recovery from acidification in European surface waters. Hydrol. Earth Syst. Sci., 5, 283-297.

Gebhardt, H., 1994. Ökologisches Wirkungskataster BadenWürttemberg: Auswirkungen der Gewässerversauerung auf Fische in Fließgewässern. Umweltministerium BadenWürttemberg: Saurer Regen - Probleme für Wasser, Boden und Organismen, Umweltforschung in Baden-Württemberg. Ecomed, Landsberg, 251-282.

Hedin, L.O., Granat, L., Likens, G.E., Buishand, T.A., Galloway, J.N., Butler, T.J. and Rodhe, H., 1994. Steep declines in atmospheric base cations in regions of Europe and North America. Nature, 367, 351-354.

Hinderer, M. and Einsele, G., 1998. Grundwasserversauerung in Baden-Württemberg, Landesanstalt für Umweltschutz. Handbuch Wasser, 3, 1-210.

Johnson, D.W., Cresser, M.S., Nilsson, I.S., Turner, J., Ulrich, B., Binkley, D. and Cole, D.W., 1991. Soil changes in forest ecosystems: Evidence for and possible causes. Proc. Roy. Soc. Edinburgh, 97B, 81-116.

Kreutzer, K., 1994. The influence of catchment management processes in forests on the recovery in fresh waters. In: Acidification of freshwaters: Implications for the future, C.E.W. Steinberg and R.F. Wright (Eds.), Wiley, New York, 325-344.

Lehmann, M., 2000. Untersuchungen der Belastungen von Rohwässern der BEW GmbH am Ochsenkopf (Fichtelgebirge), Diplomarbeit an der Universität Bayreuth, zweite veränderte Fassung, 1-107. 
Lenz, R.J.M., Müller, A. and Erhard, M., 1994. Veränderungen der Säureneutralisationskapazität nordostbayerischer Wälder. Forstarchiv, 65, 172-182.

Leßmann, D., Avermann, T., Coring, E. and Rüddenklau, R., 1994. Fließgewässerbiozönosen. In: Gefahr für Ökosysteme und Wasserqualität: Ergebnisse interdisziplinärer Forschung im Harz, J. Matschullat, H. Heinrichs, J. Schneider and B. Ulrich (Eds.). Springer, Berlin, 317-378.

LfW, 1994. Bayerisches Landesamt für Wasserwirtschaft. Auswirkungen des Sauren Regens und des Waldsterbens auf das Grundwasser. Dokumentation der Methoden und Meßdaten des Entwicklungsvorhabens 1988-1992. Materialien Nr. 40, Eignenveralg, Munchen, 1-387.

LfW, 1997. Bayerisches Landesamt für Wasserwirtschaft. Grundwasserversauerung in Bayern. Informationsberichte, 1/ 97, 1-178.

LfW, 1998. Bayerisches Landesamt für Wasserwirtschaft. Monitoringprogramm für versauerte Gewässer durch Luftschadstoffe in der Bundesrepublik Deutschland im Rahmen der ECE: Bericht der Jahre 1995-1996. Materialien Nr., 76, 165.

LfW, 1999. Bayerisches Landesamt für Wasserwirtschaft. Versauerung oberirdischer Gewässer in Bayern. Entwicklung 1983 - 1996. Informationsberichte, 4/99, 1-343.

Likens, G.E., Bormann, F.H., Pierce, R.S., Eaton, J.S. and Johnson, N.M., 1977. Biogeochemistry of a forested ecosystem. Springer, New York, 1-146.

Lorenz, M., 1995. International Co-operative Programme on Assessment and Monitoring of Air Pollution Effects on Forests -ICP Forests. Water Air Soil Pollut., 85, 1221-1226.

Lovett, G.M., Bowser, J.J. and Edgerton, E.S., 1997. Atmospheric deposition to watersheds in complex terrain. Hydrol. Process., 11, 645-654.

Malmer, N., 1976. Chemical changes in the soil. Ambio, 5, 231234.

Manderscheid, B. and Göttlein, A., 1995. Wassereinzugsgebiet 'Lehstenbach' - das BITÖK-Untersuchungsgebiet am Waldstein (Fichtelgebirge, NO-Bayern). Bayreuther Forum Ökologie, 18, $1-84$.

Matzner, E., 1988. Der Stoffumsatz zweier Waldökosysteme im Solling. Ber. des Forschungszentrums Waldökosysteme/ Waldsterben, Reihe A, 40, 1-217.

Meesenburg, H., Meiwes, K.J. and Rademacher, P., 1995. Long term trends in atmospheric deposition and seepage output in northwest German forest ecosystems. Water Air Soil Pollut., 85, 611-616.

Meesenburg, H., Meiwes, K.J., Wagner, M. and Prenzel, J., 2001. Ecosystem effects after ameliorative liming of a catchment at the Harz mountains, Germany. Dev. Plant Soil Sci., (in press).

Moritz, K. and Bittersohl, J., 2000. Turnover of nitrogen and acidfication in the small headwater catchment Markungsgraben. Silva Gabreta, 4, 63-70.

Musibono, D.E. and Day, J.A., 1999. The effect of Mn on mortality and growth in the freshwater amphipod Paramelita Nigroculus (Barnard) exposed to a mixture of $\mathrm{Al}$ and $\mathrm{Cu}$ in acidic waters. Water Res., 33, 207-213.

Müller-Edzards, C., de Vries, W. and Erisman, J.W., 1997. Ten years of Monitoring Forest Condition in Europe. Studies on Temporal Development, Spatial Distribution and Impacts of Natural and Anthropogenic Stress Factors. Technical Background Report of the Convention on Long Range Transboundary Air Pollution International Cooperative Programme on Assessment and Monitroing of Air Pollution Effects on Forests. Federal Research Centre for Foresty and Forest Products. EC-UN/ECE Brussels, Geneva, 1-386.
Prechtel, A., Alewell, C., Armbruster, M., Bittersohl, J., Cullen, J., Evans, C.D., Helliwell, R., Kopacek, J., Marchetto, A., Matzner, E., Meesenburg, H., Moldan, F., Moritz, K., Vesely, J. and Wright, R.F., 2001. Response of sulphur fluxes in European freshwaters to decreasing sulphate deposition. Hydrol. and Earth Syst. Sci., 5, 311-325.

Raben, G., Andreae, H. and Meyer-Heisig, M., 2000. Long term acid load and its consequences in forest ecosystems of Saxony (Germany). Water Air Soil Pollut., 122, 93-103.

Reuss, J.O. and Johnson, D.W, 1986. Acidic deposition and the acidification of soils and waters. Springer, New York, 1-119.

Riek, W. and Wolff, B., 1998. Verbreitung von Nährstoffmangel bei Waldbäumen in Deutschland. AFZ/Der Wald, 10, 507-510.

Rhode, H., Grenfelt, P., Wisniewski, J., Ågren, C., Bengtsson, G., Hultberg, H., Johansson, K., Kaupi, P., Kucera, V., Oskarson, H., Pihl Karlsson G., Rasmussen, L., Rosseland, B., Schotte, L., Sellden, G. and Thörnelöf, E., 1995. Acid Reign '95? Conference Summary Statement from the 5th International Conference on Acidic Deposition. Science and Policy. Kluwer Academic Publishers, Göteborg, 1-15.

Schaumburg, J., 2000. Long-term trends in biology and chemistry of the acidified Bavarian Forest lakes. Silva Gabreta, 4, 2940.

Schmidt, S., 1997. Zusammenhang von Wasser- und Stoffhaushalt in der Langen Bramke -Vergleich unterschiedlicher zeitlicher und räumlicher Maßstäbe. Ber. des Forschungszentums Waldökosysteme, Reihe A, 146, 1-188.

Struys-Ponsar, C., Guillard, O. and van den Bosch deAguilar, P., 2000. Effects of aluminum exposure on glutamate metabolism: A possible explanation for its toxicity. Exp. Neurology, 163, $157-164$

Sullivan, T.J., Eilers, J.M., Cosby, B.J. and Vache, K.B., 1997. Increasing role of nitrogen in the acidification of nitrogen in the Adirondack Mountains, New York. Water Air Soil Pollut, 95, 313-336.

Ulrich, B., 1994. Nutrient and acid-base budget of central European forest ecosystems. In: Effects of Acid rain on Forest Processes, D.L. Godbold and A. Hüttermann (Eds.), 1-50. Wiley-Liss, Inc. New York.

Ulrich, B. and Sumner, M.E., 1991. Soil Acidity. Springer, Berlin.

Ulrich, B., Mayer, R. and Khanna, P.K., 1980. Chemical changes due to acid precipitation in a loess-derived soil in central Europe. Soil Sci., 130, 193-199.

Verity, M.A., 1999. Mangenese neutotoxicity: A mechanistic hypothesis. NeuroToxicol., 20, 489-498.

Wesselink, L.G., Meiwes, K.-J., Matzner, E. and Stein, A., 1995. Long-term changes in water and soil chemistry in spruce and beech forests, Solling, Germany. Environ. Sci. Technol., 29, 5158.

Wright, R.F., Alewell, C., Cullen, J., Evans, C.D., Marchetto, A., Moldan, F., Prechtel, A. and Rogora, M., 2001. Trends in nitrogen deposition and leaching in acid-sensitive streams in Europe. Hydrol. Earth Syst. Sci., 5, 299-310.

Yanai, R.D., Siccama, T.G., Arthur, M.A., Federer, C.A. and Friedland, A.J., 1999. Accumulation and depletion of base cations in forest floors in the Northeastern United States. Ecology, 80, 2774-2787.

Yokel, R.A., 2000. The toxicology of aluminum in the brain: A review. NeuroToxicol., 21, 813-828.

Zimmermann, L., Moritz, K., Kennel, M. and Bittersohl, J., 2000. Influence of bark beetle infestation on water quantity and quality in the Große Ohe catchment (Bavarian Forest National Park). Silva Gabreta, 4, 51-62. 